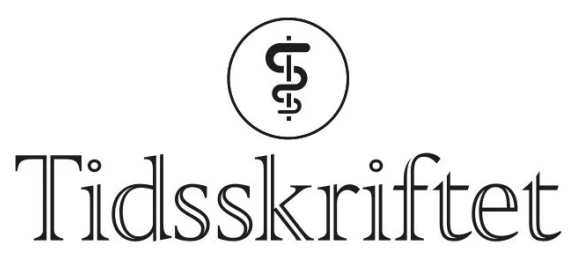

DEN NORSKE LEGEFORENING

\title{
Genterapi for mitokondriesykdommer?
}

MEDISINSK NYTT

ÅSLAUG HELLAND

Email: aslaug.helland@gmail.com

Tidsskriftet

\section{Egg som inneholder kjernen fra én donor og mitokondrier fra en annen, åpner for mulig behandling av visse arvelige mitokondriesykdommer.}

Mitokondrier og dermed mitokondrielt DNA overføres kun fra mor. Fars mitokondrier bidrar ikke. Mutasjoner i mitokondrielt DNA forårsaker forskjellige sykdommer som myopati, slagliknende episoder, hørselstap og diabetes. Mitokondriesykdommer oppstår hos ca. 1:5 ooo, men forskning viser at de kan være enda hyppigere. Ny forskning i en apemodell har vist at det er mulig å erstatte ikke-funksjonelt mitokondrielt DNA med frisk mitokondrielt DNA fra en annen donor (1) .

Forskerne brukte ikke-fertiliserte egg fra to rhesus macaque-hunnaper. Først fjernet de kjerne-DNA fra eggene, en teknisk svært vanskelig oppgave. Deretter tok de kromosomene fra en donor og fusjonerte disse med egg uten kjerne fra den andre donoren. De benyttet et viralt ekstrakt som induserer fusjon. Resultatet blir et egg med kjerne-DNA fra én donor og mitokondrielt DNA fra den andre. Eggene ble fertilisert og implantert i ni hunnaper, og det ble født tre friske apebabyer.

- At dette er blitt teknisk mulig, er svært spennende, da det foreløpig ikke finnes gode behandlingsmuligheter for de aller fleste mitokondriesykdommer, sier professor Laurence Bindoff ved Nevrologisk avdeling, Haukeland universitetssykehus.

- Vi sitter imidlertid igjen med flere spørsmål av både teknisk og ikke minst etisk art: Hvor trygt er det å bruke viralt ekstrakt? Hvor mye av cytosol fra «kjernedonoren» overføres? Kan humane kromosomer identifiseres slik at de også kan isoleres? I dag vil det ikke være etisk mulig å gjennomføre et slikt fors $\emptyset \mathrm{k}$ hos mennesker. Skulle de tekniske problemene likevel bli løsbare, kan vi kanskje se frem mot en mulig behandling for sykdommer som hittil har vært uhelbredelige, sier Bindoff. 
1. Tachibana M, Sparman M, Sritanaudomchai H et al. Mitochondrial gene replacement in primate offspring and embryonic stem cells. Nature 2009; 461:367-71.

Publisert: 17. desember 2009. Tidsskr Nor Legeforen. DOI: 10.4045/tidsskr.09.1398

(C) Tidsskrift for Den norske legeforening 2023. Lastet ned fra tidsskriftet.no 26. april 2023. 